Article

\title{
High Temperature Rotational Rheology of the Seed Flour to Predict the Texture of Canned Red Kidney Beans (Phaseolus vulgaris)
}

\author{
Richard Park ${ }^{1}$, Laura Roman ${ }^{1, *} \mathbb{B}$, Louis Falardeau ${ }^{2}$, Lionel Albino ${ }^{3}$, Iris Joye ${ }^{4}$ and \\ Mario M. Martinez $1,5, *$ (D) \\ 1 School of Engineering, University of Guelph, Guelph, ON N1G 2W1, Canada; parkr@uoguelph.ca \\ 2 Bonduelle Americas, 540 Chemin des Patriotes, St-Denis-Sur_Richelieu, QC J0H 1K0, Canada; \\ louis.falardeau@bonduelle.com \\ 3 Bonduelle, Rue Nicolas Appert, F-59653 Villeneuve d'Ascq, France; lionel.albino@bonduelle.com \\ 4 Department of Food Science, University of Guelph, Guelph, ON N1G 2W1, Canada; ijoye@uoguelph.ca \\ 5 Department of Food Science, iFOOD Interdisciplinary Center, Aarhus University, 8200 Aarhus N, Denmark \\ * Correspondence: lromanri@uoguelph.ca (L.R.); mm@food.au.dk (M.M.M.)
}

Received: 18 June 2020; Accepted: 23 July 2020; Published: 26 July 2020

check for updates

\begin{abstract}
The pasting profile of starchy tissues is conventionally measured by recording the apparent viscosity $(\eta)$ in heating/cooling cycles. However, conventional rheometers show critical limitations when the starch is embedded in compact protein-rich cotyledon matrices, as occurs in pulses. In this work, the pasting profile of 13 red kidney beans (Phaseolus vulgaris) from the same cultivar but different growing locations was investigated using a heating/cooling cycle at higher temperature $\left(130^{\circ} \mathrm{C}\right)$ and pressurized conditions, using both water and brine as cooking solvents. It was hypothesized that the continuous measure of $\eta$ at these conditions of flours from the dry seed would correlate with the texture, as determined by the mini-Kramer cell, of the beans after the entire process of soaking and canning. Furthermore, mechanistic answers were obtained by investigating their composition (starch, protein, and ash content) and physical properties (water holding capacity, seed ratio and weight). Interestingly, as opposed to the pasting profile at $95^{\circ} \mathrm{C}$, pasting indicators at $130{ }^{\circ} \mathrm{C}$, including trough and final viscosity, strongly correlated with starch and protein content, seed coat ratio and, remarkably, with the firmness of the beans after canning when brine was incorporated. These results clearly show that small beans with a high protein content would bring about a more compact matrix that restricts starch from swelling and results in canned beans with a hard texture, which can be predicted by a lower pasting profile of the whole bean flour.
\end{abstract}

Keywords: rheology; pasting profile; starch gelatinization; red kidney beans; canning

\section{Introduction}

The demand for plant-based proteins is rapidly growing with increased awareness of the carbon footprint caused by a meat-based diet. Among plant protein sources, pulses are in the spotlight for their high content in protein, carbohydrates, including dietary fiber, and minerals and vitamins [1-3]. In fact, the consumption of pulses has been associated with a reduced prevalence of type 2 diabetes and cardiovascular disease [4]. Abdullah et al. [4] estimated that an increased consumption of pulses to $100 \mathrm{~g}$ /day per person could save up to CAD USD 315 million on healthcare costs annually in Canada, attributed to anticipated reduced incidence of type 2 diabetes, colon cancer, and cardiovascular disease. Although the consumption of pulses is on the rise, already reaching $10-40 \mathrm{~kg} / \mathrm{capita}$ per year in Latin America and South Asia, its consumption remains lower than health recommendations in some other 
countries. As an example, pulse consumption still remains low in Canada, with only $13 \%$ of the adult population reporting the consumption of pulses (at an average of $113 \mathrm{~g}$ ) on any given day [5].

Traditional cooking and commercial canning processes are used to soften the bean texture, which results in a safe and palatable food. However, traditional cooking is labor- and time-intensive, and often unsuitable for urban settings where preparation time is a major constraint. Thus, ready-to-eat canned beans play a major role in some individuals' diet and are in high demand by the food industry, fast-food restaurants and households. The quality of canned beans can vary greatly, and consumers demand beans with proper integrity, a pleasant flavor profile, and pleasant firmness/tenderness [6]. The firmness of canned beans, one of their most important quality traits, varies from too firm ('tough beans') to too soft ('mushy beans'), with texture standards established for each type and pack style of canned beans [7]. Instrumental texture readings determine the firmness or softness of a sample and serve as a proxy of how beans will feel in the mouth, i.e., they serve as a useful estimator for consumer's acceptance. In addition, previous studies identified a positive correlation between appearance and texture [8], since excessive tissue softening might often be accompanied by a loss of whole bean integrity [9-11]. The texture of canned beans is influenced by a plethora of intrinsic (microstructure and composition as affected by genotype and growing conditions) and extrinsic factors (seed handling during storage and processing conditions during soaking, blanching and canning) and it is assessed by determining the amount of force $(\mathrm{kg})$ required to crush a sample of $100 \mathrm{~g}$ of cooked beans [10,11]. However, this method requires beans going through the entire time-consuming canning process prior to texture evaluation and the use of a significant amount of dry beans. Thus, rapid methods for predicting the texture of canned beans could become instrumental for both bean breeders, producers and processors. Mendoza et al. [11] investigated the feasibility of using non-destructive optical sensors (visible/near-infrared spectroscopy and hyperspectral imaging) as a predictor for canned black bean firmness. After building a model using parameters from spectroscopy and hyperspectral imaging of dry beans against actual obtained canned bean firmness values, the calibration and prediction data overlapped well with the prediction models, having a regression line of $R=0.886$ for visible/near-infrared spectroscopy and $R=0.844$ for hyperspectral imaging. However, large datasets using various phenotypic diversities must be obtained to be able to develop a robust prediction model with other bean varieties. Moreover, data must be preprocessed using different smoothing and deconvolution methods. Overall, this might require the presence of skillful workers and a significant amount of time.

The structure of the dry bean comprises a seed coat and an embryonic cotyledon. The cotyledon makes up approximately $90 \%$ of the total dry weight in the mature bean with around $40 \%$ starch, $27.5 \%$ protein, $3.5 \%$ ash and $1.65 \%$ lipids. During processing, protein will absorb water at room temperature during soaking, which will subsequently enable the starch (surrounded by protein bodies) to absorb water during the hydrothermal processing, such as blanching and cooking [12,13]. Khanal et al. [10] found that the genotype and location of harvest both had a significant impact on the protein and starch content of the beans, as well as on the texture of the beans after canning. Hence, based on the water (or brine) absorption and swelling capacity of the most predominant cotyledon components, it is hypothesized that rheological indicators from a dispersion of dry bean flour in water would correlate with the final texture of canned whole beans.

The apparent viscosity measured during a heating/cooling cycle, i.e., pasting profile, could provide useful indicators of the behavior of samples during hydrothermal processing. Typically, the maximum hold temperature during this rheological test is $95^{\circ} \mathrm{C}$, which is the maximum temperature attainable by most instruments without water evaporation. Briefly, the apparent viscosity of starch/flour in a liquid medium starts increasing rapidly mostly due to the swelling of starch granules (starting with the disruption of the hydrogen bonds in amorphous regions and water absorption). As the temperature increases, more hydration and more swelling occurs in amorphous regions, pulling apart crystallites, whose regions also eventually undergo hydration and melt [14]. Leaching of polymer molecules, such as soluble pectin, amylopectin and especially amylose, also occurs. Eventually, a peak viscosity, primarily resulting from swollen granules, is reached. During the $95{ }^{\circ} \mathrm{C}$ hold, the fragile swollen flour 
particles disintegrate under the shear conditions of the instrument, and the viscosity decreases to a trough viscosity (a process called breakdown). The degree of fragmentation depends on the shear time, and nature of the sample. As the hot paste begins to cool, it develops distinct solid properties and the apparent viscosity raises again, i.e., gelation occurs [14]. These rheological measurements can be obtained with the so-called empirical rheometers that are robust, capable of withstanding demanding factory environments and do not require highly skilled or technically trained personnel. Interestingly, some of these apparatuses, such as the RVA 4800, are able to reach temperatures of up to $140{ }^{\circ} \mathrm{C}$ under pressurized conditions to resemble hydrothermal processing above $95^{\circ} \mathrm{C}$ (typical upper limit of commercial viscosimeters due to water evaporation), which is particularly important when working with protein-rich tissue matrices that make starch more resistant to gelatinization [15]. Thus, the main aim of this work is to find meaningful correlations between the texture of canned beans and rheological indicators of the dry seed flour during a heating cooling cycle using an RVA 4800, which could result in significant savings of time during the textural evaluation of canned beans. Furthermore, physical and compositional analyses, including weight per bean, seed coat (hull) to whole-seed ratio, water-holding capacity, protein, starch and ash content, were measured to provide mechanistic understanding about the factors affecting canned bean texture, which has never been provided in a systematic manner.

\section{Materials and Methods}

\subsection{Materials}

Thirteen whole red kidney beans (Phaseolus vulgaris), from the same variety but varying in growing locations, were provided by Bonduelle Group in collaboration with Hensall Co-op. To obtain whole bean flours for analyses, beans were cryo-milled for $2 \mathrm{~min}$ in a coffee grinder (Black+Decker CBG100SC, Middleton, WI, USA) and sifted under a 250-micrometer mesh sieve (Retsch AS 200, Haan, Germany). The ground whole flours were stored in a freezer at $-20^{\circ} \mathrm{C}$ until further analyses in order to minimize any enzymatic activity in the sample. For individual compositional analyses on seed coat and cotyledon of the beans, coats and cotyledons were manually separated, cryo-milled and stored as aforementioned. Cotyledons were cryo-milled as above detailed for the whole beans, but for the seed coat, a ball mill (Retsch PM 100, Haan, Germany) set at $6 \mathrm{~min}$ at $600 \mathrm{rpm}$ was used, as the coats were too light and difficult to mill otherwise.

\subsection{Methods}

\subsubsection{Compositional Analysis of Beans}

Proximate compositional analyses were performed at least in duplicate. Moisture content of whole bean flours was measured using an automated moisture analyzer (Sartorius MA35, Goettingen, Germany) in accordance with AACC method 44-15.02 [16]. Ash in the whole flours was analyzed according to AACC 923.03 method. Protein content of seed coat and cotyledon was determined using the combustion method according to AACC method 46-30.01 with an automated Dumas protein analysis system [16] (Leco FP-528, St. Joseph, MI, USA), using the factor of 6.25 to convert the measured nitrogen into protein. Total starch content of cotyledon was measured using the Megazyme total starch kit (K-TSTA-100A, Wicklow, Ireland) according to AACC method 76-13. [16].

\subsubsection{Physical Analysis of Beans}

Seed weight was determined in duplicate by weighing $50.0 \pm 0.2 \mathrm{~g}$ of beans and dividing it by the number of beans manually counted in the $50 \mathrm{~g}$ of sample. The water-holding capacity (WHC) of intact whole beans was measured in accordance to the AACC 56-35 method [16] with some modifications. A total of $25 \mathrm{~g}$ of beans were soaked in $100 \mathrm{~g}$ of distilled water at 1:4 (sample:water, $w / w$ ) ratio for 
$16 \mathrm{~h}$ at room temperature. After draining, the beans were left to dry on a paper towel for $5 \mathrm{~min}$ and weighed. WHC was assessed in duplicate and was calculated on dry basis as follows:

$$
\operatorname{WHC}(\%)=\frac{100 \times\left(\mathrm{W}_{2}-\mathrm{W}_{1}\right)}{\mathrm{W}_{1} \times\left(100-\mathrm{M}_{\mathrm{c}}\right)} \times 100
$$

where $\mathrm{W}_{1}$ = weight of seeds before soaking, $\mathrm{W}_{2}=$ weight of seeds after soaking, and $\mathrm{M}_{\mathrm{c}}=$ the moisture content, expressed as a percentage by mass, of the seeds.

Seed coat to whole seed ratio was determined in triplicate by weighing and soaking $25 \mathrm{~g}$ of beans at room temperature in distilled water for $75 \mathrm{~min}$ to facilitate separation of the coat layer from the cotyledon tissue. After $75 \mathrm{~min}$, coats were separated manually from cotyledons and the two fractions were dried in an oven for $16 \mathrm{~h}$ at $40{ }^{\circ} \mathrm{C}$ until constant weight. After $16 \mathrm{~h}$, seed coat and cotyledon fractions were weighed separately and seed coat to whole seed ratio was calculated as shown in Equation (2).

$$
\text { Seed coat to whole seed ratio }=\frac{\text { Weight }(\mathrm{g}) \text { of dried seed coat }}{(\text { Weight }(\mathrm{g}) \text { of dried cot yledon }+ \text { dried seed coat })} \times 100
$$

\subsubsection{Pasting Profiles of Whole Bean Flours}

The pasting profiles of whole bean flours were measured using a Rapid Visco-Analyzer (RVA 4800 Perten Instruments, Sydney, Australia) equipped with a canister and paddle system able to work under retort (high pressure and high temperature) conditions. Pasting profiles of the flours were obtained following the typical standard pasting cycle at $95^{\circ} \mathrm{C}$ hold temperature according to AACC method 61-02.01 [16], as well as the high-temperature pasting cycle $\left(130^{\circ} \mathrm{C}\right.$ hold temperature), as described by Perten Instruments [17] using $4.0 \mathrm{~g}$ of flour and $25 \mathrm{~mL}$ ultrapure water (Table 1). The $130{ }^{\circ} \mathrm{C}$ hold pasting profiles were also obtained using brine $\left(1.5 \%\right.$ sucrose, $\left.1.2 \% \mathrm{NaCl}, 0.03 \% \mathrm{CaCl}_{2}\right)$ instead of water, with a $\mathrm{pH}$ of 5.9. The brine was prepared as reported by Mendoza et al. [11]. A comparative example of RVA profiles at 95 and $130^{\circ} \mathrm{C}$ from the same red kidney bean flour sample are shown in Figure 1 , where a noticeable underdeveloped pasting profile at $95^{\circ} \mathrm{C}$ is depicted. The pasting profiles were used to obtain the following parameters based on the viscosity values: peak viscosity (PV, highest viscosity reached during heating), trough viscosity (lowest viscosity reached during the holding/cooling stage), breakdown viscosity (difference between the peak viscosity and the trough), final viscosity (viscosity at the end of the test) and setback (difference between trough viscosity and final viscosity). The time to reach peak viscosity (peak time) and the time that gives rise to $50 \%$ of peak viscosity (time for PV/2) were also included as descriptors of the resistivity of the flour particles to swell during heating. Finally, the temperature at which the viscosity starts to increase rapidly is also recorded (pasting temperature). RVA measurements were performed at least in duplicate. It is noteworthy that the relative standard deviation, $\mathrm{RSD}=(\mathrm{SD} /$ average $) \times 100$, was $<10 \%$ for 203 out of the 208 values obtained running the $\mathrm{RVA}$, and, in most cases, $<5 \%$.

Table 1. Standard pasting profile at $130{ }^{\circ} \mathrm{C}$ used for measuring pasting properties of whole bean flours (adapted from Perten Instruments, 2017).

\begin{tabular}{ccc}
\hline Time (Minutes) & Parameter & $\mathbf{1 3 0}{ }^{\circ} \mathbf{C}$ Hold Temperature Cycle \\
\hline $00: 00$ & Temperature & $50{ }^{\circ} \mathrm{C}$ \\
$00: 00$ & Speed & $960 \mathrm{rpm}$ \\
$00: 10$ & Speed & $160 \mathrm{rpm}$ \\
$01: 00$ & Temperature & $50{ }^{\circ} \mathrm{C}$ \\
$07: 40$ & Temperature & $130{ }^{\circ} \mathrm{C}$ \\
$10: 10$ & Temperature & $130^{\circ} \mathrm{C}$ \\
$16: 50$ & Temperature \\
$18: 50$ & End & $50^{\circ} \mathrm{C}$ \\
\hline
\end{tabular}




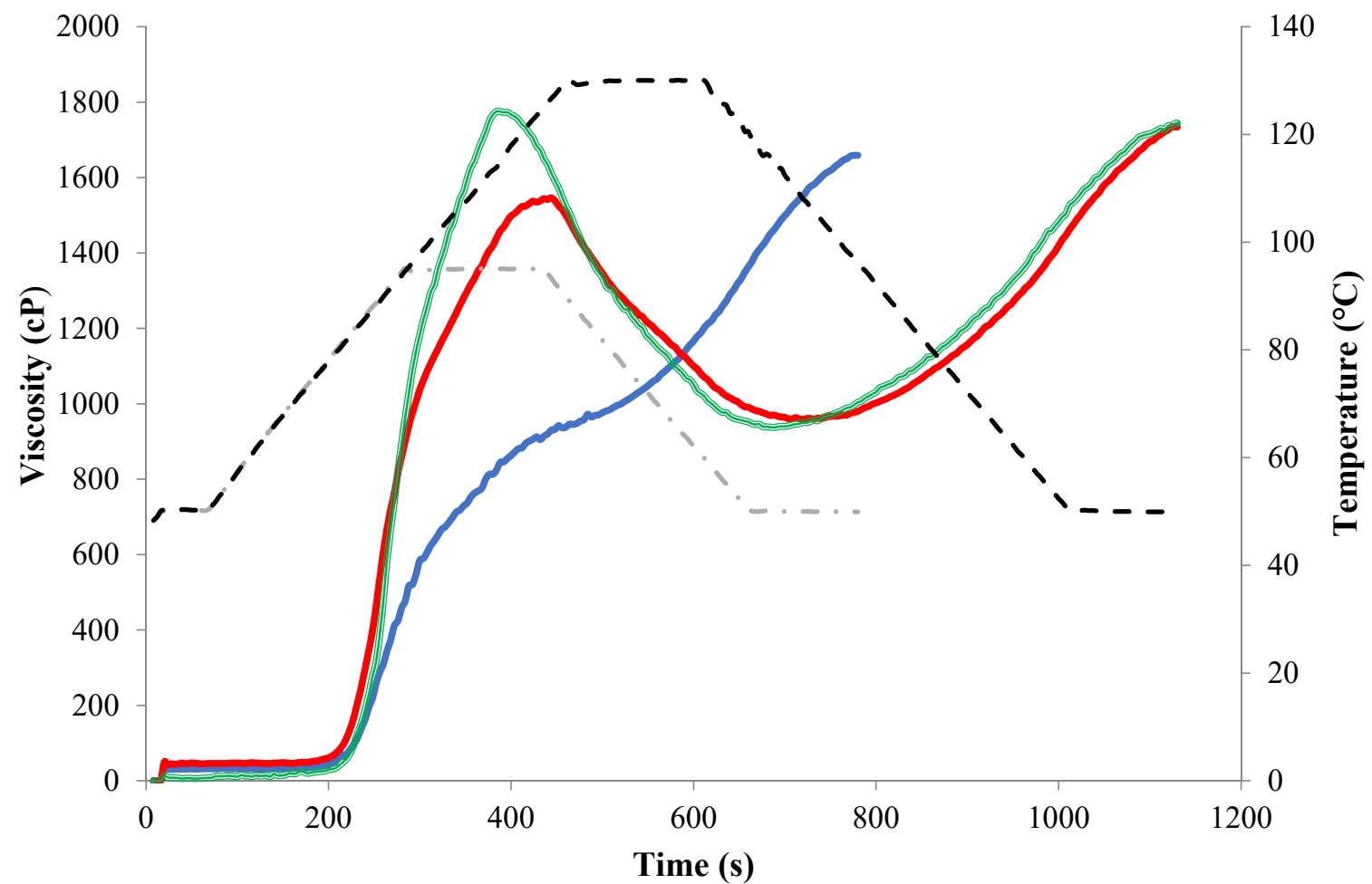

Figure 1. Pasting profiles of whole bean flour with different mediums and two different temperature profiles. The same red kidney bean flour was used to perform the three pasting profiles represented in this figure. Blue line, pasting profile with holding time at $95^{\circ} \mathrm{C}$ using water; Red line, pasting profile with holding time at $130{ }^{\circ} \mathrm{C}$ using water; Green line, pasting profile with holding time at $130{ }^{\circ} \mathrm{C}$ using brine $\left(1.5 \%\right.$ sucrose, $\left.1.2 \% \mathrm{NaCl}, 0.03 \% \mathrm{CaCl}_{2}\right)$. Discontinues grey and black lines represent the temperature as a function of time in standard $\left(95^{\circ} \mathrm{C}\right)$ and pressurized high temperature $\left(130{ }^{\circ} \mathrm{C}\right)$ RVA tests, respectively.

\subsubsection{Canning of Whole Beans}

For canning, $50.0 \pm 0.2 \mathrm{~g}$ of raw beans were weighed, counted and soaked for $6 \mathrm{~h}$ in four times the seed weight of distilled water ( $200 \mathrm{~g})$. After soaking, the beans were drained and allowed to dry on a paper towel for $5 \mathrm{~min}$. Subsequently, the soaked beans were placed in $250 \mathrm{~mL}$ mason jars, covered with brine (1.5\% sucrose, $\left.1.2 \% \mathrm{NaCl}, 0.03 \% \mathrm{CaCl}_{2}\right)$ up to $2 \mathrm{~cm}$ from the top of the jar $(120 \%$ of soaked weight), as reported in Mendoza et al. [11]. Using an automated pressure cooker filled with $1.5 \mathrm{~L}$ of ultrapure water (Instant Pot Max, Kanata, ON, Canada), the samples were pre-heated to $121^{\circ} \mathrm{C}$ and $15 \mathrm{psi}$ for $24 \mathrm{~min}$. Afterwards, the jars were retorted at $121^{\circ} \mathrm{C}, 15 \mathrm{psi}$ for $6 \mathrm{~min}$ (according to the canning settings) and then the steam was immediately released (quick release setting). The number of jars in the cooker was controlled to seven at a time, with one of the jars being filled with distilled water and placed in the middle of the cooker, to make sure all the six remaining jars containing beans received the same amount of heat. After cooking, the jars were cooled under tap water $\left(20^{\circ} \mathrm{C}\right)$ for $20 \mathrm{~min}$, and stored at room temperature until further analysis. This cooling was performed to reduce integrity loss from overcooking and minimize growth of thermophilic bacteria [18]. Cooking experiments were performed in duplicate.

\subsubsection{Texture Analysis of Canned Beans}

The canned beans were analyzed $24 \mathrm{~h}$ after retorting. Jars were opened and beans were drained and dried on a paper towel for $5 \mathrm{~min}$. Firmness analysis was conducted using a texture analyzer (TA.XT2. plus, Texture Technologies. Corp., Scarsdale, NY, USA) equipped with a $20 \mathrm{~kg}$ load cell according to the AACC method 56-36.01 [19]. $7.5 \pm 0.5 \mathrm{~g}$ of beans were loaded into a mini Kramer 
shear cell holder (HDP/MK05, Stable Micro Systems, Surrey, UK). The probe started at $30 \mathrm{~mm}$ above zero, and cooked beans were compressed and extruded at $1.5 \mathrm{~mm} / \mathrm{s}$ with a five-blade shear probe until reaching the cell's bottom. The firmness $(\mathrm{N})$ of the sample was determined as the maximum force of the peak obtained. An average of minimum four replications was used.

\subsubsection{Statistical Analysis}

Statistical analysis was conducted using Statistical Package for the Social Sciences (SPSS), including the $t$-test for significance of differences in averages between the two RVA mediums, significance of difference between samples using analysis of variance (one way ANOVA-post-hoc with Tukey's HSD), Pearson's bivariate correlations matrix, and linear regression — the best model after correlation. All tests were done at a $95 \%$ confidence interval.

\section{Results}

\subsection{Composition, Water Holding Capacity and Physical Properties of Dry Beans}

Results for compositional analyses of red kidney beans are reported in Table 2. The moisture of the whole seeds ranged from 12.64 to $16.86 \%$ (always below 17\%). During harvest and upon arrival of the beans to the reception facility, beans are usually subjected to drying in order to avoid microbial spoilage so that the beans can preserve their quality for long storage periods before processing [20]. The ash content of whole seeds slightly varied between samples, with values from 3.32 to $3.91 \%$ (dry basis (d.b.)), which agrees with values reported in the literature for red kidney beans [21]. The major compounds, starch and protein were measured separately in the coat (hull) and de-hulled seed (cotyledon) to obtain complimentary information about the location of these major compounds. Total starch content was only measured in cotyledons, since it is well known that seed coat does not possess starch [22]. Starch was found to be the main component in bean cotyledons, ranging from 41.59 to $48.47 \%$ (d.b.). The protein content ranged from 22.31 to $31.98 \%$ (d.b.) in the cotyledon and 4.61 to $6.24 \%$ (d.b.) in the seed coat. This is in line with the physiology of pulses, as protein is mainly found in the cotyledon as protein bodies [22]. All these values for starch and protein are in line with those previously reported in the literature [22-26]. In addition, the compositional results confirm that the growing location of the same bean genotype influences their composition, and, in turn, functionality during canning.

The dry seed weight, seed coat to whole seed ratio (seed coat ratio), and WHC, are also reported in Table 2 and they were correlated with the major compounds. The weight per bean varied from 0.50 to $0.74 \mathrm{~g}$, with only slightly higher values than those found in the literature amongst various types of Phaseolus vulgaris including red kidney beans $[27,28]$. The seed coat ratio ranged from 7.23 to $8.81 \%$. It has been reported that seed coats constitute approximately $8 \%$ of the weight of the beans and that it, together with the total starch content in the cotyledon, influences the cooking time of the bean [29]. These weight and size differences can lead to different soaking and cooking behaviors of the seeds, as will be discussed below. As starch is the largest component in cotyledon (which constitutes the main fraction of the seed), the weight per bean significantly correlated to the starch content in the cotyledon $(\mathrm{r}=0.912, p<0.01)$ and, hence, it correlated negatively to protein content in cotyledon $(\mathrm{r}=-0.789$, $p<0.01)$ and seed coat $(r=-0.716, p<0.01)$.

The WHC of the beans, measured after soaking for $16 \mathrm{~h}$ at room temperature, ranged from 120.40 to $138.92 \%$ (expressed on weight percent basis). At room temperature, starch granules are insoluble in water and possess a low water absorption capacity, meaning that only protein and non-starch polysaccharides will be responsible for absorbing and bonding water [30]. In fact, WHC was positively correlated with the protein content in the cotyledon $(\mathrm{r}=0.764, p<0.01)$. In addition, WHC was negatively correlated to the weight per bean $(\mathrm{r}=-0.703, p<0.01)$, which could be explained by the smaller surface area, and possibly relatively smaller micropyle and hilum sizes, also leading to higher seed coat ratio and protein content, as mentioned above. 
Table 2. Proximate analysis results of 13 red kidney bean samples

\begin{tabular}{|c|c|c|c|c|c|c|c|c|}
\hline Sample & $\begin{array}{c}\text { Whole Bean } \\
\text { Moisture } \\
\text { (\% w.b.) }\end{array}$ & $\begin{array}{c}\text { Total Starch } \\
\text { Cotyledon } \\
\text { (\%, d.b.) }\end{array}$ & $\begin{array}{l}\text { Protein } \\
\text { Cotyledon } \\
(\%, \text { d.b. })\end{array}$ & $\begin{array}{l}\text { Protein Seed } \\
\text { Coat }(\%, \text { d.b. })\end{array}$ & $\begin{array}{c}\text { Ash Whole } \\
\text { Seed }(\%, \text { d.b. })\end{array}$ & $\begin{array}{c}\text { Weight Per } \\
\text { Bean (g) }\end{array}$ & $\begin{array}{c}\text { Seed Coat } \\
\text { Ratio (\%) }\end{array}$ & WHC (\%) \\
\hline 1 & $15.59 \mathrm{~cd} \pm 0.54$ & $45.98 \mathrm{~cd} \pm 0.32$ & $26.77 j \pm 0.01$ & $4.91 b \pm 0.01$ & $3.85 \mathrm{ef} \pm 0.04$ & $0.64 \mathrm{de} \pm 0.02$ & $7.42 \mathrm{abc} \pm 0.15$ & $130.78 \mathrm{fg} \pm 0.11$ \\
\hline 2 & $14.58 c \pm 0.52$ & $48.47 \mathrm{e} \pm 0.38$ & $22.36 b \pm 0.01$ & $5.33 g \pm 0.01$ & $3.40 \mathrm{a} \pm 0.01$ & $0.72 \mathrm{fg} \pm 0.01$ & $7.56 \mathrm{abcd} \pm 0.15$ & $123.89 b c \pm 0.57$ \\
\hline 3 & $12.64 \mathrm{a} \pm 0.24$ & $46.35 c d \pm 0.02$ & $24.32 \mathrm{f} \pm 0.01$ & $4.90 b \pm 0.01$ & $3.61 b c \pm 0.06$ & $0.68 \mathrm{ef} \pm 0.01$ & $7.34 \mathrm{ab} \pm 0.08$ & $120.40 \mathrm{a} \pm 0.62$ \\
\hline 4 & $14.45 b c \pm 0.01$ & $41.59 \mathrm{a} \pm 0.39$ & $31.98 \mathrm{~m} \pm 0.00$ & $6.24 \mathrm{i} \pm 0.01$ & $3.89 \mathrm{f} \pm 0.01$ & $0.50 \mathrm{a} \pm 0.02$ & $8.81 \mathrm{f} \pm 0.04$ & $133.06 \mathrm{~g} \pm 0.31$ \\
\hline 5 & $11.78 a \pm 0.77$ & $46.58 \mathrm{~cd} \pm 0.34$ & $22.79 c \pm 0.01$ & $5.06 \mathrm{~d} \pm 0.01$ & $3.78 \mathrm{def} \pm 0.03$ & $0.62 \mathrm{~cd} \pm 0.02$ & $7.23 a \pm 0.02$ & $127.42 \mathrm{de} \pm 0.42$ \\
\hline 6 & $12.98 \mathrm{ab} \pm 0.21$ & $44.08 b \pm 0.11$ & $30.121 \pm 0.01$ & $6.23 \mathrm{hi} \pm 0.01$ & $3.68 \mathrm{bcd} \pm 0.03$ & $0.58 b c \pm 0.02$ & 7.89de \pm 0.14 & $129.41 \mathrm{ef} \pm 0.60$ \\
\hline 7 & $11.55 a \pm 0.26$ & $45.63 b c \pm 0.12$ & $25.04 \mathrm{i} \pm 0.01$ & $5.14 \mathrm{e} \pm 0.01$ & $3.84 \mathrm{ef} \pm 0.01$ & $0.69 \mathrm{ef} \pm 0.01$ & $7.33 \mathrm{ab} \pm 0.07$ & $121.16 \mathrm{ab} \pm 1.29$ \\
\hline 8 & $14.31 b c \pm 0.71$ & $47.68 \mathrm{de} \pm 0.73$ & $24.21 \mathrm{e} \pm 0.01$ & $5.30 \mathrm{~g} \pm 0.01$ & $3.32 \mathrm{a} \pm 0.03$ & $0.71 \mathrm{fg} \pm 0.01$ & $7.66 \mathrm{bcd} \pm 0.14$ & $124.01 b c \pm 0.72$ \\
\hline 9 & $16.54 d \pm 0.26$ & 46.91cde \pm 1.14 & $24.95 h \pm 0.01$ & $5.22 \mathrm{f} \pm 0.00$ & $3.73 \mathrm{cde} \pm 0.04$ & $0.74 \mathrm{~g} \pm 0.01$ & $7.70 \mathrm{cde} \pm 0.02$ & $131.52 \mathrm{fg} \pm 0.43$ \\
\hline 10 & $15.72 \mathrm{~cd} \pm 0.55$ & $46.37 \mathrm{~cd} \pm 0.31$ & $24.49 g \pm 0.01$ & $4.61 \mathrm{a} \pm 0.01$ & $3.84 \mathrm{ef} \pm 0.02$ & $0.67 \mathrm{ef} \pm 0.02$ & $7.58 b c d \pm 0.15$ & $128.94 \mathrm{ef} \pm 0.30$ \\
\hline 11 & $16.86 \mathrm{~d} \pm 0.25$ & $46.59 \mathrm{~cd} \pm 0.16$ & $23.32 \mathrm{~d} \pm 0.00$ & $5.03 \mathrm{~d} \pm 0.01$ & $3.64 b c \pm 0.04$ & $0.66 \mathrm{de} \pm 0.01$ & $7.74 \mathrm{cde} \pm 0.07$ & $123.77 \mathrm{~cd} \pm 2.09$ \\
\hline 12 & $16.41 d \pm 0.15$ & $45.77 c d \pm 0.45$ & $22.31 \mathrm{a} \pm 0.01$ & $4.97 c \pm 0.01$ & $3.58 b \pm 0.01$ & $0.64 \mathrm{de} \pm 0.02$ & $7.73 \mathrm{cde} \pm 0.04$ & $125.76 \mathrm{~cd} \pm 0.87$ \\
\hline 13 & $14.72 c \pm 0.23$ & $41.95 \mathrm{a} \pm 0.23$ & $29.97 \mathrm{k} \pm 0.01$ & $6.20 h \pm 0.01$ & $3.91 \mathrm{f} \pm 0.04$ & $0.55 b \pm 0.02$ & $8.05 e \pm 0.12$ & $138.92 \mathrm{~h} \pm 0.18$ \\
\hline
\end{tabular}




\subsection{Pasting Properties of the Whole Bean Flour}

The results of RVA parameters obtained at high temperature conditions $\left(130{ }^{\circ} \mathrm{C}\right)$ using water and brine as a cooking medium are found in Tables 3 and 4, respectively. In addition, the differences in the average values of all samples for each pasting parameter are shown in Table 5. In Figure 1, pasting profiles obtained under pressurized high temperature $\left(130^{\circ} \mathrm{C}\right)$ conditions where compared to the standard $95^{\circ} \mathrm{C}$ pasting profile using AACC 61-02.01 method [16]. During the conventional pasting profile at $95^{\circ} \mathrm{C}$, a defined peak viscosity was not clearly visible for the bean flour, i.e., the pasting curve was not fully developed. Therefore, the standard $95{ }^{\circ} \mathrm{C}$ pasting profile failed at providing quantitative rheological indicators (i.e., pasting parameters could not accurately be calculated). In contrast, the profiles obtained using the pressurized $130{ }^{\circ} \mathrm{C}$ procedure (with water or brine) displayed a complete pasting profile with pronounced peak, breakdown, and setback viscosities, as seen in Figure 1. Thus, only indicators from the $130{ }^{\circ} \mathrm{C}$ pasting profiles are discussed in this work. Pulse flours contain high amounts of protein and thick cell walls surrounding starch granules, which might restrict heat and mass transfer to the starch granules, impairing full gelatinization, which can be achieved with a conventional pasting profile only reaching $95^{\circ} \mathrm{C}$ [15]. It can also be seen that, when using the cooking brine instead of ultrapure water as an RVA medium, peak time decreased, and peak viscosity increased significantly, as also displayed in Figure 1, indicating the faster hydration and cooking of bean flours in the presence of salts [29]. To understand the different pasting behavior observed for the two cooking media, two plausible explanations are possible. Firstly, increased denaturation temperature of the proteins vicilins (7S) and legumins (11S), which represent $\sim 65 \%$ of all the common bean proteins, in the presence of ions in the medium during hydrothermal processing, was previously reported in the literature [31,32]. Increasing ionic strength impacts the functionality of the salt soluble vicilins (7S) and legumins (11S), leading to stronger bonds that make the protein more resistant to denaturation $[33,34]$. Therefore, the salt concentration in the brine used in this study would increase the denaturation temperature of the globulins up to $5{ }^{\circ} \mathrm{C}$ [32]. This would separate the state transitions between the $7 \mathrm{~S}$ protein (with peak temperature of denaturation at $\sim 78^{\circ} \mathrm{C}$ in water [35]) and starch (with peak temperature of gelatinization at $\sim 79{ }^{\circ} \mathrm{C}[36]$ ), allowing the starch gelatinization to happen with less interruption from a denatured protein network. In fact, the presence of denatured proteins has been found to impair starch swelling and gelatinization [37,38]. These observations align with the results obtained by Joshi et al. [39], where the peak viscosity increased and peak time decreased with less protein in the mixture. Research conducted on the impact of salts on the pasting properties of isolated starches showed different results for different starch types [40,41]. However, no research has been conducted on the impact of salts on pulse flours, where a full pasting peak can only be obtained with high-pressure cooking conditions, as opposed to standard $95{ }^{\circ} \mathrm{C}$ procedures (Figure 1). Secondly, the change in the pasting curve shape may be due to the salt-solubility of globulins in the bean [42]. Up to $\sim 90 \%$ of proteins in legumes are found to be salt-soluble [43]. As the brine solubilizes surface proteins bound to the starch granules and allows the starch to be more readily exposed to hydration [44], it would bring the earlier and more prominent pasting profile shown in Figure 1. In addition, the higher peak viscosity, breakdown and setback found with brine ( $\mathrm{pH}$ 5.9) compared to water ( $\mathrm{pH} \sim 7$ ) also suggests a better solubilization of cell-wall components with slightly acidic conditions, which may be linked to the facilitation of the cleavage of strong bonds between protopectin and other cell wall materials [45].

As seen in Table 6 where Pearson correlations between bean attributes are summarized, starch and protein were significantly correlated to all RVA parameters except for peak time. In general, all pasting parameters that correlated positively with starch correlated negatively with protein in both seed coat and cotyledon fractions. Interestingly, using brine increased the correlation of all pasting parameters to the starch and protein content, except for trough viscosity.

The peak viscosity in brine was the parameter that correlated the strongest to total starch in cotyledon $(\mathrm{r}=0.908, p<0.01)$, meaning that a higher starch content (the one responsible for swelling) resulted in higher peak viscosity. Meanwhile, to reach half the viscosity value of the peak viscosity (time 
for PV/2) in both water and brine strongly correlated with protein in cotyledon and seed coat $(\mathrm{r}=0.935$ and $\mathrm{r}=0.836$, respectively, for water, and $\mathrm{r}=0.928$ and $\mathrm{r}=0.884$, respectively, for brine, all $p<0.01$ ). The time for PV/2 is a more recent parameter that was adapted by Palabiyik et al. (2017) [46] to determine the resistivity of starch against processing conditions such as shearing, where a higher value means higher resistivity. Again, this will imply that a higher protein content results in higher resistivity of the flour particles to swell during heating, and, thus, a more delayed starch swelling and viscosity development.

Considering all the pasting parameters together, a higher amount of starch in the beans, and then, lower protein content, resulted in higher viscosity changes during the whole heating-cooling cycle, namely higher peak (maximum), trough (minimum) and final viscosities as well as higher setback and breakdown. In addition, lower pasting temperature and time to reach half the peak viscosity were also obtained with higher starch content and lower protein content. Altogether, these results would indicate that a higher and earlier swelling is obtained with the higher presence of starch in the cotyledon, as starch gelatinization and retrogradation are the main phenomena responsible for viscosity changes during the pasting profile. In contrast, a thicker or higher presence of a protein matrix in the bean flour, would hinder viscosity changes due to the physical limitations of starch swelling and water competition.

Among all pasting parameters, physical bean characteristics were best correlated (highest $r$ coefficient values) to the time for PV/2 in both water and brine, indicative of the cotyledon resistivity to swell, demonstrating that time for $\mathrm{PV} / 2$ may be a good indicator for starch/protein content in beans. Together with time for $\mathrm{PV} / 2$, pasting temperature was also a good indicator of starch and protein content, as the high $\mathrm{r}$ values denote, regardless of the type of medium used, as there was no significant impact of the cooking medium on these values, as shown in Table 5. Another interesting point to note is that, although the peak viscosity changed in the curves shown in Figure 1, the time to reach half of this viscosity (Time for PV/2) did not, making it an interesting value to differentiate compositional attributes in bean flours. Time for PV/2 also showed a high correlation with WHC, seed weight and seed coat ratio (in brine, $0.804,-0.811$ and 0.653 , respectively, $p<0.01$ ). These physical attributes were also correlated to other pasting parameters, like pasting temperature or final viscosity, as detailed in Table 6. It is important to highlight that these correlations, less strong than the protein and starch ones with pasting parameters, should be understood based on the existing correlation of physical and compositional attributes of the beans, as explained in Section 3.1. As an example, a higher WHC was obtained in beans with higher protein content in the sample, therefore, WHC is correlated in the same manner to pasting parameters as it does protein content. 
Table 3. RVA parameters of 13 bean flours obtained using distilled water with a pressurized system reaching $130{ }^{\circ} \mathrm{C}$.

\begin{tabular}{|c|c|c|c|c|c|c|c|c|}
\hline Sample & $\begin{array}{l}\text { Time for } \mathrm{pv} / 2 \\
\text { (s) }\end{array}$ & $\begin{array}{l}\text { Peak Viscosity } \\
\text { (cp) }\end{array}$ & $\begin{array}{l}\text { Trough Viscosity } \\
\text { (cp) }\end{array}$ & $\begin{array}{l}\text { Breakdown } \\
\quad(\mathrm{cp})\end{array}$ & $\begin{array}{l}\text { Final Viscosity } \\
\text { (cp) }\end{array}$ & $\begin{array}{l}\text { Setback } \\
\text { (cp) }\end{array}$ & $\begin{array}{l}\text { Peak Time } \\
\text { (s) }\end{array}$ & $\begin{array}{c}\text { Pasting Temp. } \\
\left({ }^{\circ} \mathrm{C}\right)\end{array}$ \\
\hline 1 & $285.40 \mathrm{c} \pm 2.90$ & $1628 \mathrm{ef} \pm 72$ & $998 \mathrm{e} \pm 28$ & $631 \mathrm{~g} \pm 61$ & $1804 \mathrm{ef} \pm 27$ & $806 \mathrm{def} \pm 7$ & $7.38 b c \pm 0.22$ & $83.27 a b c \pm 0.45$ \\
\hline 2 & $264.53 \mathrm{ab} \pm 0.37$ & 1445 bcde \pm 1 & $945 \mathrm{cde} \pm 6$ & 500def \pm 6 & $1685 \mathrm{de} \pm 16$ & $741 \mathrm{bcd} \pm 22$ & $6.97 a \pm 0.05$ & $81.55 a \pm 1.70$ \\
\hline 3 & $272.22 b \pm 3.83$ & $1178 a \pm 48$ & $807 a b \pm 26$ & $372 \mathrm{abc} \pm 22$ & $1489 b c \pm 38$ & $683 b \pm 14$ & $7.75 d \pm 0.04$ & $82.68 \mathrm{ab} \pm 0.03$ \\
\hline 4 & $300.59 \mathrm{~d} \pm 1.71$ & $1001 a \pm 66$ & $733 a \pm 28$ & $268 \mathrm{a} \pm 37$ & $1249 a \pm 54$ & $517 a \pm 26$ & $7.20 \mathrm{abc} \pm 0.13$ & $85.38 \mathrm{bcd} \pm 0.49$ \\
\hline 5 & $271.51 \mathrm{ab} \pm 2.43$ & $1420 \mathrm{bcd} \pm 6$ & $867 \mathrm{bc} \pm 20$ & $553 \mathrm{efg} \pm 25$ & $1609 \mathrm{~cd} \pm 19$ & $742 \mathrm{bcde} \pm 1$ & $7.53 \mathrm{~cd} \pm 0.00$ & $82.73 \mathrm{ab} \pm 0.04$ \\
\hline 6 & $306.45 d \pm 0.52$ & $1100 a \pm 43$ & $799 a b \pm 9$ & $301 \mathrm{ab} \pm 52$ & $1319 a \pm 6$ & $520 \mathrm{a} \pm 3$ & $7.17 \mathrm{ab} \pm 0.05$ & $86.68 \mathrm{~d} \pm 1.10$ \\
\hline 7 & $263.19 a \pm 3.32$ & $1380 \mathrm{~b} \pm 71$ & $904 \mathrm{~cd} \pm 21$ & $476 \mathrm{cde} \pm 51$ & 1712 def \pm 71 & $809 \mathrm{f} \pm 50$ & $7.40 b c \pm 0.10$ & $81.95 a+1.13$ \\
\hline 8 & $268.63 a b \pm 2.72$ & $1391 b c \pm 10$ & $973 \mathrm{de} \pm 6$ & $419 \mathrm{bcd} \pm 16$ & 1690de \pm 19 & $717 b c \pm 13$ & $7.07 a b \pm 0.09$ & $82.70 \mathrm{ab} \pm 0.07$ \\
\hline 9 & $270.02 \mathrm{ab} \pm 1.19$ & $1640 \mathrm{f} \pm 43$ & $1027 \mathrm{e} \pm 12$ & $612 \mathrm{fg} \pm 36$ & $1835 f \pm 33$ & $808 \mathrm{ef} \pm 24$ & $7.15 \mathrm{ab} \pm 0.04$ & $81.63 a \pm 0.88$ \\
\hline 10 & $271.60 \mathrm{ab} \pm 1.13$ & 1538 bcdef \pm 83 & $949 \mathrm{cde} \pm 43$ & $589 \mathrm{efg} \pm 54$ & 1730def \pm 54 & 781 cdef \pm 12 & $7.32 b c \pm 0.10$ & $82.31 a \pm 0.84$ \\
\hline 11 & $265.82 \mathrm{ab} \pm 5.72$ & 1572 cdef \pm 33 & 988 de \pm 40 & $584 \mathrm{efg} \pm 30$ & $1833 f \pm 30$ & $846 f \pm 11$ & $7.17 \mathrm{ab} \pm 0.05$ & $81.53 a \pm 1.66$ \\
\hline 12 & $271.31 \mathrm{ab} \pm 0.11$ & 1609 def \pm 23 & $994 \mathrm{de} \pm 10$ & $615 f g \pm 23$ & $1832 \mathrm{f} \pm 23$ & $838 f \pm 13$ & $7.10 \mathrm{ab} \pm 0.04$ & $82.65 a b \pm 0.00$ \\
\hline 13 & $307.40 \mathrm{~d} \pm 2.55$ & $1087 \mathrm{a} \pm 27$ & $801 \mathrm{ab} \pm 14$ & $286 a \pm 27$ & $1370 \mathrm{ab} \pm 27$ & $569 a \pm 13$ & $6.87 \mathrm{a} \pm 0.00$ & $85.88 \mathrm{~cd} \pm 0.04$ \\
\hline
\end{tabular}

Table 4. RVA parameters of 13 bean flours obtained using brine with a pressurized system reaching $130{ }^{\circ} \mathrm{C}$.

\begin{tabular}{|c|c|c|c|c|c|c|c|c|}
\hline Sample & $\begin{array}{l}\text { Time for } \mathrm{pv} / 2 \\
\text { (s) }\end{array}$ & $\begin{array}{l}\text { Peak Viscosity } \\
\text { (cp) }\end{array}$ & $\begin{array}{l}\text { Trough Viscosity } \\
\text { (cp) }\end{array}$ & $\begin{array}{l}\text { Breakdown } \\
\quad(\mathrm{cp})\end{array}$ & $\begin{array}{l}\text { Final Viscosity } \\
\text { (cp) }\end{array}$ & $\begin{array}{l}\text { Setback } \\
\text { (cp) }\end{array}$ & $\begin{array}{l}\text { Peak Time } \\
\text { (s) }\end{array}$ & $\begin{array}{c}\text { Pasting Temp. } \\
\left({ }^{\circ} \mathrm{C}\right)\end{array}$ \\
\hline 1 & $291.70 b \pm 1.28$ & $1928 c \pm 47$ & $1006 d \pm 13$ & $922 \mathrm{cde} \pm 61$ & 1849 cde \pm 12 & $843 \mathrm{cde} \pm 25$ & $6.57 \mathrm{a} \pm 0.05$ & $85.20 b c d \pm 0.07$ \\
\hline 2 & $282.56 a b \pm 2.07$ & $1979 c \pm 28$ & $989 d \pm 31$ & $990 \mathrm{de} \pm 3$ & $1944 \mathrm{e} \pm 35$ & $955 \mathrm{f} \pm 4$ & $6.50 \mathrm{a} \pm 0.14$ & $82.68 \mathrm{ab} \pm 0.04$ \\
\hline 3 & $285.54 a b \pm 2.49$ & $1880 c \pm 16$ & $980 \mathrm{~cd} \pm 5$ & $901 \mathrm{bcde} \pm 11$ & 1810 cde \pm 16 & $831 \mathrm{bcde} \pm 11$ & $6.57 \mathrm{a} \pm 0.05$ & $82.70 \mathrm{ab} \pm 0.00$ \\
\hline 4 & $308.22 c \pm 2.16$ & $1597 a b \pm 8$ & $794 a \pm 8$ & $803 a b c \pm 16$ & $1530 \mathrm{a} \pm 7$ & $736 a b c \pm 16$ & $6.64 \mathrm{a} \pm 0.05$ & $84.35 a b c \pm 1.13$ \\
\hline 5 & $281.93 a b \pm 2.75$ & $1949 c \pm 33$ & $988 d \pm 23$ & 961 cde \pm 11 & 1817 cde \pm 57 & $829 \mathrm{bcde} \pm 34$ & $6.37 \mathrm{a} \pm 0.05$ & $82.75 a b \pm 0.07$ \\
\hline 6 & $308.16 c \pm 0.91$ & $1605 a b \pm 19$ & $881 \mathrm{abc} \pm 15$ & $724 a b \pm 4$ & $1603 a b \pm 30$ & $722 \mathrm{ab} \pm 16$ & $6.44 \mathrm{a} \pm 0.05$ & $85.90 \mathrm{~cd} \pm 0.07$ \\
\hline 7 & $286.46 a b \pm 1.17$ & $1826 b c \pm 42$ & $948 \mathrm{~cd} \pm 20$ & 878 bcde \pm 22 & $1748 \mathrm{bcd} \pm 23$ & $800 \mathrm{bcd} \pm 3$ & $6.54 \mathrm{a} \pm 0.09$ & $84.35 a b c \pm 1.13$ \\
\hline 8 & $279.51 \mathrm{a} \pm 1.96$ & $1895 c \pm 197$ & $988 \mathrm{~d} \pm 55$ & $907 \mathrm{bcde} \pm 142$ & $1896 \mathrm{cde} \pm 128$ & $908 \mathrm{def} \pm 73$ & $6.43 a \pm 0.14$ & $83.15 a b c \pm 0.64$ \\
\hline 9 & $283.23 a b \pm 3.59$ & $1949 c \pm 40$ & $923 \mathrm{bcd} \pm 37$ & 1026de \pm 3 & $1802 \mathrm{cde} \pm 45$ & 879 def \pm 8 & $6.40 \mathrm{a} \pm 0.10$ & $82.78 a b \pm 0.04$ \\
\hline 10 & $279.24 a \pm 0.51$ & $1795 b c \pm 28$ & $944 c d \pm 7$ & $851 \mathrm{bcd} \pm 21$ & $1749 \mathrm{bcd} \pm 6$ & $805 b c d \pm 1$ & $6.47 a \pm 0.09$ & $83.13 a b c \pm 0.06$ \\
\hline 11 & $281.41 \mathrm{a} \pm 5.32$ & $1878 \mathrm{c} \pm 40$ & $835 \mathrm{ab} \pm 43$ & $1044 \mathrm{e} \pm 4$ & $1718 \mathrm{bc} \pm 25$ & $884 \mathrm{def} \pm 18$ & $6.44 \mathrm{a} \pm 0.05$ & $82.38 \mathrm{a} \pm 1.73$ \\
\hline 12 & $279.13 a \pm 1.65$ & $1913 c \pm 28$ & $987 d \pm 13$ & $926 \mathrm{cde} \pm 41$ & $1917 \mathrm{de} \pm 33$ & $931 \mathrm{ef} \pm 46$ & $6.37 \mathrm{a} \pm 0.14$ & $82.73 \mathrm{ab} \pm 0.04$ \\
\hline 13 & $316.08 c \pm 2.31$ & $1543 a \pm 25$ & $919 b c d \pm 4$ & $624 a \pm 21$ & $1606 a b \pm 1$ & $687 a \pm 4$ & $6.60 a \pm 0.18$ & $87.53 d \pm 0.04$ \\
\hline
\end{tabular}

Average values \pm standard deviation under the same column with same letter are not significantly different $(p<0.05)$. Time for PV/2: time to reach half peak viscosity. 
Table 5. Average values of RVA parameters at $130^{\circ} \mathrm{C}$ for 13 bean flours using distilled water and brine.

\begin{tabular}{|c|c|c|c|c|c|c|c|c|}
\hline Medium Type & $\begin{array}{c}\text { Time for } \mathrm{pv} / 2 \\
\text { (s) }\end{array}$ & $\begin{array}{l}\text { Peak Viscosity } \\
\text { (cp) }\end{array}$ & $\begin{array}{c}\text { Trough } \\
\text { Viscosity (cp) }\end{array}$ & $\begin{array}{l}\text { Breakdown } \\
\text { (cp) }\end{array}$ & $\begin{array}{l}\text { Final Viscosity } \\
\text { (cp) }\end{array}$ & $\begin{array}{l}\text { Setback } \\
\text { (cp) }\end{array}$ & Peak Time (s) & $\begin{array}{c}\text { Pasting Temp } \\
\left({ }^{\circ} \mathrm{C}\right)\end{array}$ \\
\hline Water & $278.62 \mathrm{a} \pm 16.30$ & $1383 a \pm 214$ & $907 a \pm 93$ & $476 a \pm 129$ & $1629 a \pm 200$ & $722 \mathrm{a} \pm 114$ & $7.24 a \pm 0.25$ & $83.15 a \pm 1.69$ \\
\hline Brine & $289.00 \mathrm{a} \pm 13.83$ & $1826 b \pm 149$ & $937 a \pm 66$ & $889 b \pm 118$ & $1768 b \pm 127$ & $831 b \pm 82$ & $6.48 b \pm 0.09$ & $83.81 \mathrm{a} \pm 1.57$ \\
\hline
\end{tabular}

Average values \pm standard deviation under the same column with same letters are not significantly different $(p<0.05)$. Time for PV/2: time to reach half peak viscosity.

Table 6. Pearson's correlation between pasting properties of bean flours and compositional and physical properties of the dry beans studied.

\begin{tabular}{|c|c|c|c|c|c|c|c|c|c|}
\hline $\begin{array}{c}\text { RVA } \\
\text { Parameter }\end{array}$ & RVA Medium & $\begin{array}{c}\text { Whole Bean } \\
\text { Moisture (\%) }\end{array}$ & $\begin{array}{l}\text { Total Starch in } \\
\text { Cotyledon (\%) }\end{array}$ & $\begin{array}{c}\text { Protein in } \\
\text { Cotyledon (\%) }\end{array}$ & $\begin{array}{c}\text { Protein in } \\
\text { Seed Coat }(\%)\end{array}$ & Ash (\%) & $\begin{array}{l}\text { Weight Per } \\
\text { Bean (g) }\end{array}$ & $\begin{array}{l}\text { Seed Coat } \\
\text { Ratio (\%) }\end{array}$ & WHC (\%) \\
\hline Time for PV/2 & Water & 0.209 & $-0.878^{* *}$ & $0.935^{* *}$ & $0.836^{* *}$ & 0.482 & $-0.869^{* *}$ & $0.702 * *$ & $0.841^{* *}$ \\
\hline$(\mathrm{s})$ & Brine & 0.070 & $-0.888^{* *}$ & $0.928 * *$ & $0.884^{* *}$ & 0.461 & $-0.811^{* *}$ & $0.653 *$ & $0.804^{* *}$ \\
\hline Peak viscosity & Water & 0.226 & $0.716^{* *}$ & $-0.744^{* *}$ & $-0.786^{* *}$ & -0.205 & $0.701^{* *}$ & -0.525 & $-0.569 *$ \\
\hline$(\mathrm{cP})$ & Brine & -0.093 & $0.908^{* *}$ & $-0.888^{* *}$ & $-0.813^{* *}$ & -0.495 & $0.816^{* *}$ & $-0.710^{* *}$ & $-0.703^{* *}$ \\
\hline Trough & Water & 0.281 & $0.726^{* *}$ & $-0.686^{* *}$ & $-0.681 *$ & -0.354 & $0.755^{* *}$ & -0.457 & $-0.586^{*}$ \\
\hline viscosity $(\mathrm{cP})$ & Brine & -0.332 & $0.616^{*}$ & -0.613 * & $-0.585^{*}$ & -0.355 & 0.578 * & $-0.780^{* *}$ & -0.251 \\
\hline Breakdown & Water & 0.175 & $0.671^{*}$ & $-0.746^{* *}$ & $-0.820^{* *}$ & -0.087 & 0.624 * & -0.547 & -0.528 \\
\hline$(\mathrm{cP})$ & Brine & 0.067 & $0.799 * *$ & $-0.775^{* *}$ & $-0.697^{* *}$ & -0.424 & $0.705^{* *}$ & -0.46 & $-0.744^{* *}$ \\
\hline Final viscosity & Water & 0.122 & $0.746^{* *}$ & $-0.787^{* *}$ & $-0.813^{* *}$ & -0.270 & $0.768^{* *}$ & $-0.572 *$ & -0.665 * \\
\hline$(\mathrm{CP})$ & Brine & -0.062 & $0.867^{* *}$ & $-0.860^{* *}$ & $-0.717^{* *}$ & -0.649 * & $0.785^{* *}$ & $-0.688^{* *}$ & $-0.642 *$ \\
\hline Setback & Water & -0.014 & $0.720 * *$ & $-0.824^{* *}$ & $-0.874^{* *}$ & -0.187 & $0.734^{* *}$ & $-0.634^{*}$ & $-0.691^{* *}$ \\
\hline$(\mathrm{cP})$ & Brine & 0.169 & $0.859^{* *}$ & $-0.851^{* *}$ & -0.650 * & $-0.728^{* *}$ & $0.762 * *$ & -0.449 & $-0.801^{* *}$ \\
\hline Peak time & Water & -0.517 & 0.225 & -0.227 & -0.547 & 0.217 & 0.166 & -0.564 * & -0.225 \\
\hline (s) & Brine & 0.036 & -0.574 * & 0.629 * & 0.391 & 0.420 & -0.46 & 0.419 & 0.374 \\
\hline Pasting temp. & Water & 0.084 & $-0.819^{* *}$ & $0.871^{* *}$ & $0.823 * *$ & 0.371 & $-0.828^{* *}$ & 0.574 * & 0.772 ** \\
\hline$\left({ }^{\circ} \mathrm{C}\right)$ & Brine & -0.020 & $-0.744^{* *}$ & $0.796^{* *}$ & $0.691 * *$ & 0.519 & -0.627 * & 0.362 & $0.788^{* *}$ \\
\hline
\end{tabular}

** Correlation is significant at the 0.01 level (2-tailed). ${ }^{*}$ Correlation is significant at the 0.05 level (2-tailed). WHC: Water-holding capacity, Time for PV/2: time to reach half peak viscosity. 


\subsection{Texture of the Canned Beans}

Firmness, obtained as the maximum-recorded force during textural analysis, was measured for the 13 bean samples $24 \mathrm{~h}$ after canning with cooking brine, and average values are reported in Figure 2 . Canned beans had a firmness range of from 118.84 to $151.84 \mathrm{~N}$ with an average of $131.09 \mathrm{~N}$.

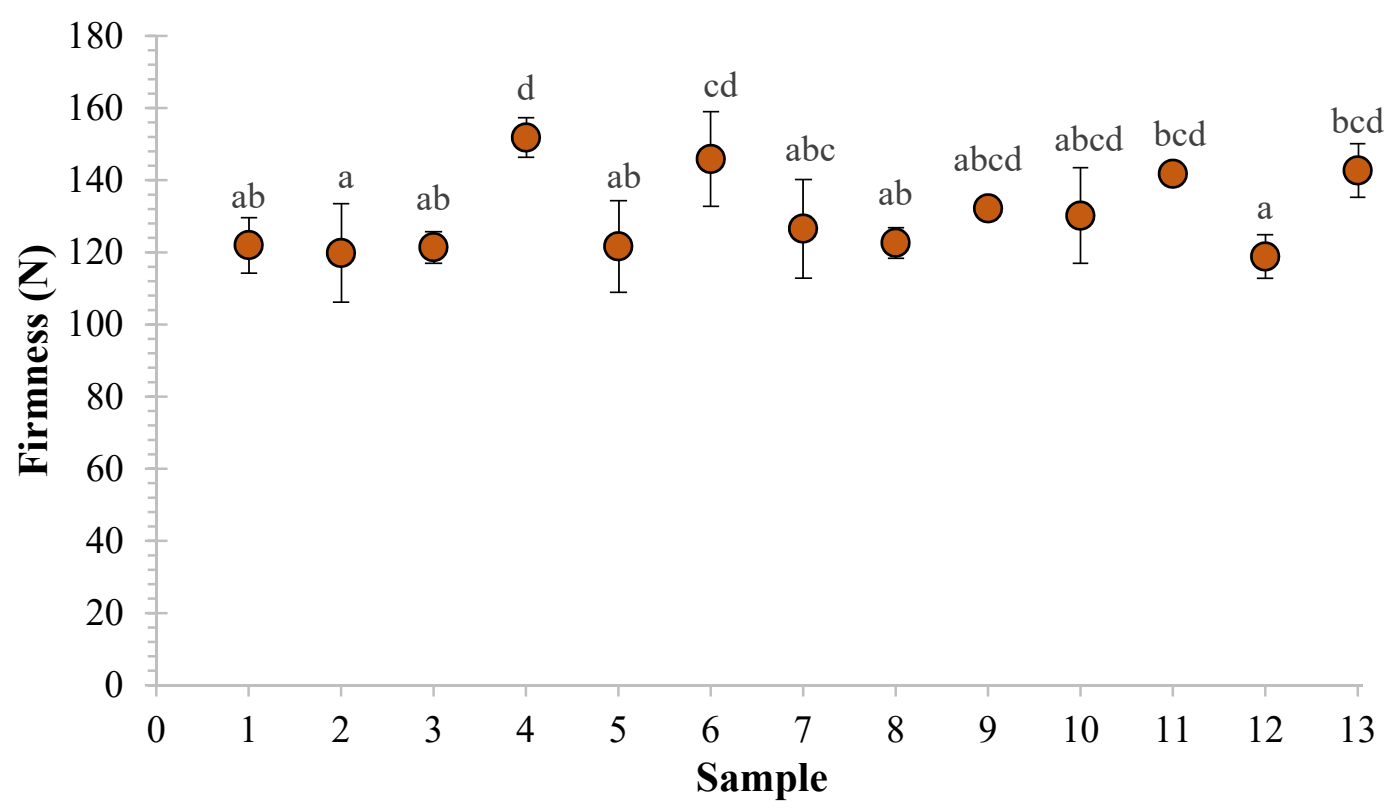

Figure 2. Visual of the distribution of average firmness values of bean samples. Error bars indicating standard deviation of firmness for each sample are included.

Correlations between firmness values and all pasting parameters/bean characteristics are shown in Table 7. It was observed that the use of cooking brine in the RVA yielded stronger correlations with bean firmness than water. This event could be attributed to the enhancement of starch swelling by the presence of salts, as discussed in Section 3.2. Among all RVA parameters, the final viscosity $(\mathrm{r}=-0.951 ; p<0.01)$ and trough viscosity $(\mathrm{r}=-0.926 ; p<0.01)$, both using brine, had a very high negative correlation with the firmness of the canned beans. In addition, peak viscosity and setback were also negatively correlated to firmness $(r=-0.820$ and -0.741 , respectively, $p<0.01)$. Although these results may seem contradictory, since a more enhanced viscosity profile with a higher final viscosity would be expected to result in higher firmness, these results should be explained based on compositional and structural attributes. Thus, the firmness of beans strongly correlated negatively with the starch $(\mathrm{r}=-0.768 p<0.01)$ and positively with protein content $(\mathrm{r}=0.785 p<0.01)$ and seed coat ratio $(\mathrm{r}=0.756 p<0.01)$. It seems that smaller beans (i.e., higher coat to cotyledon ratio and lower weight per bean) with a high protein content would bring about a more compact cotyledon matrix that restricts starch from swelling and gelatinizing, which can be seen from a lower pasting profile with lower trough and final viscosity, resulting in canned beans with higher firmness. 
Table 7. Correlations of textural properties of canned beans with the pasting properties at high temperature $\left(130^{\circ} \mathrm{C}\right)$ and compositional and physical measurements of dry seeds.

\begin{tabular}{|c|c|c|}
\hline \multicolumn{2}{|l|}{ Parameter } & \multirow{2}{*}{$\frac{\text { Firmness of Beans (N) }}{0.704^{* *}}$} \\
\hline Time for PV/2 (s) & Water & \\
\hline 1mme ior I V/2 (s) & Brine & $0.691^{* *}$ \\
\hline \multirow{2}{*}{ Peak viscosity $(\mathrm{cP})$} & Water & $-0.583 *$ \\
\hline & Brine & $-0.820^{* *}$ \\
\hline \multirow{2}{*}{ Trough viscosity $(\mathrm{cP})$} & Water & $-0.572 *$ \\
\hline & Brine & $-0.926^{* *}$ \\
\hline \multirow{2}{*}{ Breakdown $(\mathrm{cP})$} & Water & $-0.560 *$ \\
\hline & Brine & -0.516 \\
\hline \multirow{2}{*}{ Final viscosity $(\mathrm{cP})$} & Water & $-0.631 *$ \\
\hline & Brine & $-0.951 * *$ \\
\hline \multirow{2}{*}{ Setback $(c \mathrm{P})$} & Water & $-0.644 *$ \\
\hline & Brine & $-0.741^{* *}$ \\
\hline \multirow{2}{*}{ Peak time (s) } & Water & -0.337 \\
\hline & Brine & 0.321 \\
\hline \multirow{2}{*}{ Pasting temp $\left({ }^{\circ} \mathrm{C}\right)$} & Water & 0.634 * \\
\hline & Brine & 0.499 \\
\hline \multicolumn{2}{|c|}{ Total Starch in cotyledon (\%) } & $-0.768^{* *}$ \\
\hline \multicolumn{2}{|c|}{ Protein in cotyledon (\%) } & $0.785^{* *}$ \\
\hline \multicolumn{2}{|c|}{ Protein in seed coat $(\%)$} & $0.748^{* *}$ \\
\hline \multicolumn{2}{|c|}{ Ash (\%) } & 0.500 \\
\hline \multicolumn{2}{|c|}{ Whole bean moisture (\%) } & 0.205 \\
\hline \multicolumn{2}{|c|}{ Weight per bean $(\mathrm{g})$} & $-0.730^{* *}$ \\
\hline \multicolumn{2}{|c|}{ Seed coat ratio $(\%)$} & $0.756^{* *}$ \\
\hline \multicolumn{2}{|c|}{ WHC $(\%)$} & $0.557 *$ \\
\hline
\end{tabular}

** Correlation is significant at the 0.01 level (2-tailed). ${ }^{*}$ Correlation is significant at the 0.05 level (2-tailed).

Although final viscosity alone had the highest correlation with bean firmness, analyzing the RVA parameters through stepwise linear regression (Table 8) led to models indicating that the highest amount of variance (adjusted $R^{2}=0.956$ ) is covered when setback with brine is included in the model with either trough or final viscosity with brine (Model 2 and Model 4), rather than trough or final viscosity alone (Model 1 and Model 3). In this case, setback is a secondary RVA parameter and, therefore, it needs a primary indicator (either trough or final viscosity with brine) to set the base level of its impact for a correlation. Setback is reported to be an indicator of the short-term retrogradation ability of amylose after hydrothermal processing, and, thus, can be used to estimate the texture of a cooked starchy products [47-49]. In Table 8, it is shown that setback was able to distinguish more significant differences between samples (more subsets) compared to other parameters.

Table 8. Linear Regression of Firmness of Beans with RVA variables.

\begin{tabular}{ccccc}
\hline Model $^{\mathbf{a}}$ & $\mathbf{R}$ & $\mathbf{R}^{\mathbf{2}}$ & Adjusted $^{\mathbf{2}}$ & Standard. Error of the Model (\%) \\
\hline 1 & 0.926 & 0.857 & 0.844 & 4.34 \\
2 & 0.981 & 0.963 & 0.956 & 2.30 \\
3 & 0.951 & 0.904 & 0.895 & 3.55 \\
4 & 0.981 & 0.963 & 0.956 & 2.30
\end{tabular}

a Dependent Variable: Firmness of Beans. Model 1 Predictors: (Constant), Trough viscosity with Brine; Model 2 Predictors: (Constant), Trough viscosity with Brine, Setback with Brine; Model 3 Predictors: (Constant), Final viscosity with Brine; Model 4 Predictors: (Constant), Final viscosity with Brine, Setback with Brine.

As an example of the strength of the models, the normality and homoscedasticity of models 2 and 4 are shown in Figure 3. It is noteworthy that both models followed the exact same distribution of points. The variance inflation factors of model 2 (with trough viscosity and setback) and model 4 
(with final viscosity and setback) were 1.323 and 4.990, respectively. As these values were less than 10, it means that there is absence of multicollinearity in these models. This confirms that the model meets all the assumptions required for linear regression, therefore the R-value of 0.981 can be applied.
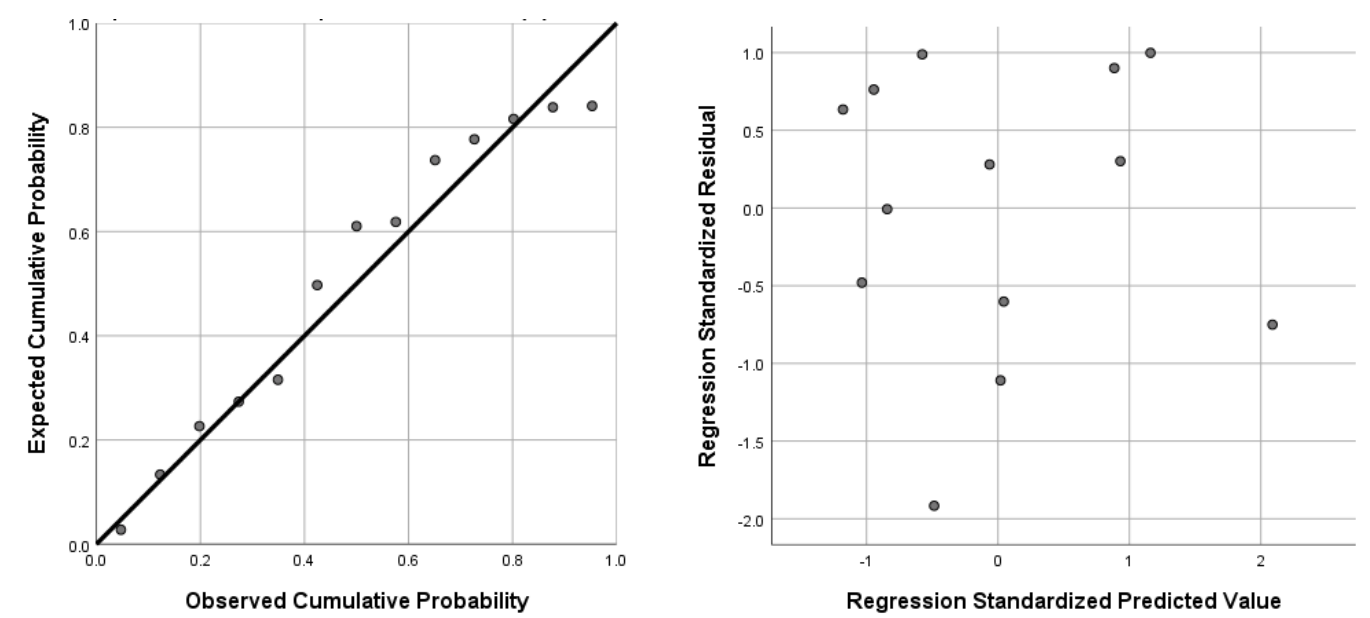

Figure 3. Normality plot of regression standardized residual and homoscedasticity scatter plot of models 2 (bean firmness with trough with brine and setback with brine) and 4 (bean firmness with final viscosity with brine and setback with brine).

\section{Conclusions}

The pressurized RVA 4800 at $130^{\circ} \mathrm{C}$ was able to bring about a fully developed viscosity curve that provided rheological indicators that were strongly correlated to the instrumentally measured texture of canned beans. Furthermore, correlations became stronger when brine was used as a cooking medium in the RVA 4800, which was attributed to either or both the partial solubilization of proteins and cell wall polysaccharides and the increase in the denaturation temperature of proteins. Since the instrumental texture of beans is assessed on bean samples after the entire process of soaking, cooking and canning (which would take more than $16 \mathrm{~h}$ ), the rapid determination of the pasting profile of the whole bean flour could save a significant amount of time (entire analysis in less than $30 \mathrm{~min}$ ) during the prediction of the texture of canned beans. Future work should be conducted to extrapolate these correlations to other types of canned pulses.

Author Contributions: Conceptualization, R.P., L.R. and M.M.M.; Funding acquisition, M.M.M.; Investigation, R.P. and L.R.; Methodology, L.R., L.F., L.A. and I.J.; Supervision, L.R. and M.M.M.; Writing-original draft, R.P.; L.R., M.M.M.; Writing-review and editing, L.R., L.F., L.A., I.J. and M.M.M. All authors have read and agreed to the published version of the manuscript.

Funding: This research was funded by the Natural Sciences and Engineering Research Council of Canada (NSERC), Collaborative Research and Development program (grant number 401407), and Bonduelle. The authors acknowledge Perten Instruments for providing RVA 4800.

Conflicts of Interest: The authors declare no conflict of interest.

\section{References}

1. Oomah, B.D.; Caspar, F.; Malcolmson, L.J.; Bellido, A.S. Phenolics and antioxidant activity of lentil and pea hulls. Food Res. Int. 2011, 44, 436-441. [CrossRef]

2. Farooq, Z.; Boye, J.I. Novel food and industrial applications of pulse flours and fractions. In Pulse Foods: Processing, Quality and Nutraceutical Applications; Tiwari, B.K., Gowen, A., McKenna, B., Eds.; Academic Press: San Diego, CA, USA, 2011; pp. 283-323, ISBN 9780123820181.

3. Tiwari, B.; Singh, N. Pulse Chemistry and Technology; The Royal Society of Chemistry: Cambridge, UK, 2012.

4. Abdullah, M.M.H.; Marinangeli, C.P.F.; Jones, P.J.H.; Carlberg, J.G. Canadian potential healthcare and societal cost savings from consumption of pulses: A cost-of-illness analysis. Nutrients 2017, 9, 793. [CrossRef] 
5. Mudryj, A.N.; Yu, N.; Hartman, T.J.; Mitchell, D.C.; Lawrence, F.R.; Aukema, H.M. Pulse consumption in Canadian adults influences nutrient intakes. Br. J. Nutr. 2012, 108, S27-S36. [CrossRef]

6. Borchgrevink, C.P. Culinary Perspective of Dry Beans and Pulses. In Dry Beans and Pulses Production, Processing and Nutrition; Siddiq, M., Uebersax, M.A., Eds.; Blackwell Publishing Ltd.: Oxford, UK, 2012; pp. 311-334, ISBN 9780813823874.

7. White, B.L.; Howard, L.R. Canned Whole Dry Beans and Bean Products. In Dry Beans and Pulses Production, Processing and Nutrition; Siddiq, M., Uebersax, M.A., Eds.; Blackwell Publishing Ltd.: Oxford, UK, 2012; pp. 155-183, ISBN 9780813823874.

8. Walters, K.; Hosfield, G.; Uebersax, M.A.; Kelly, J.D. Navy bean canning quality: Correlations, heritability estimates, and randomly amplified polymorphic DNA markers associated with component traits. J. Am. Soc. Hortic. Sci. 1997, 122, 338-343. [CrossRef]

9. Dhurandhar, N.V.; Chang, K.C. Effect of Cooking on Firmness, Trypsin Inhibitors, Lectins and Cystine/Cysteine content of Navy and Red Kidney Beans (Phaseolus vulgaris). J. Food Sci. 1990, 55, 470-474. [CrossRef]

10. Khanal, R.; Burt, A.J.; Woodrow, L.; Balasubramanian, P.; Navabi, A. Genotypic association of parameters commonly used to predict canning quality of dry bean. Crop Sci. 2014, 54, 2564-2573. [CrossRef]

11. Mendoza, F.A.; Cichy, K.A.; Sprague, C.; Goffnett, A.; Lu, R.; Kelly, J.D. Prediction of canned black bean texture (Phaseolus vulgaris L.) from intact dry seeds using visible/near infrared spectroscopy and hyperspectral imaging data. J. Sci. Food Agric. 2018, 98, 283-290. [CrossRef]

12. Berg, T.; Singh, J.; Hardacre, A.; Boland, M.J. The role of cotyledon cell structure during in vitro digestion of starch in navy beans. Carbohydr. Polym. 2012, 87, 1678-1688. [CrossRef]

13. Sefa-Dedeh, S.; Stanley, D. The relationship of microstructure of cowpeas to water absorption and dehulling properties. Cereal Chem. 1979, 56, 379-386.

14. Bemiller, J.N. Pasting, paste, and gel properties of starch-hydrocolloid combinations. Carbohydr. Polym. 2011, 86, 386-423. [CrossRef]

15. Liu, S.; Yuan, T.Z.; Wang, X.; Reimer, M.; Isaak, C.; Ai, Y. Behaviors of starches evaluated at high heating temperatures using a new model of Rapid Visco Analyzer-RVA 4800. Food Hydrocoll. 2019, 94, 217-228. [CrossRef]

16. Cereals \& Grains Association. Approved Methods of the American Association of Cereal Chemists, 11th ed.; AACC International: St. Paul, MN, USA, 2009.

17. Perten Instruments. RVA Method 45.01 High Temperature General Pasting Method. Available online: https://www.perten.com/Global/Applicationnotes/RVA/HighTemperatureGeneralPastingMethodRVA45.01.pdf (accessed on 1 May 2020).

18. Siddiq, M.; Butt, M.S.; Sultan, M.T. Dry Beans: Production, Processing, and Nutrition. In Handbook of Vegetables and Vegetable Processing; Sinha, N.K., Ed.; Blackwell Publishing Ltd.: Ames, IA, USA, 2011; pp. 545-564, ISBN 9780813815411.

19. AACC Aproved Methods of Analyses. AACC Method 56-36.01 Firmness of Cooked Pulses, AACC International: St. Paul, MN, USA, 2012, 1-4. Available online: http://methods.aaccnet.org/summaries/56-3601.aspx (accessed on 24 July 2020).

20. Mohan, R.J.; Sangeetha, A.; Narasimha, H.V.; Tiwari, B.K. Post-harvest technology of pulses. In Pulse Foods: Processing, Quality and Nutraceutical Applications; Tiwari, B.K., Gowen, A., McKenna, B., Eds.; Academic Press: San Diego, CA, USA, 2011; pp. 171-192, ISBN 9780123820181.

21. Pedrosa, M.M.; Cuadrado, C.; Burbano, C.; Muzquiz, M.; Cabellos, B.; Olmedilla-Alonso, B.; Asensio-Vegas, C. Effects of industrial canning on the proximate composition, bioactive compounds contents and nutritional profile of two Spanish common dry beans (Phaseolus vulgaris L.). Food Chem. 2015, 166, 68-75. [CrossRef] [PubMed]

22. Bewley, J.D. Seeds: Physiology of Development, Germination and Dormancy, 3rd ed.; Springer: New York, NY, USA, 2013; ISBN 9781461446934.

23. Chung, H.J.; Liu, Q.; Peter Pauls, K.; Fan, M.Z.; Yada, R. In vitro starch digestibility, expected glycemic index and some physicochemical properties of starch and flour from common bean (Phaseolus vulgaris L.) varieties grown in Canada. Food Res. Int. 2008, 41, 869-875. [CrossRef] 
24. Lopes, L.C.M.; De Aleluia Batista, K.; Fernandes, K.F.; De Andrade Cardoso Santiago, R. Functional, biochemical and pasting properties of extruded bean (phaseolus vulgaris) cotyledons. Int. J. Food Sci. Technol. 2012, 47, 1859-1865. [CrossRef]

25. de la Rosa-Millán, J.; Pérez-Carrillo, E.; Guajardo-Flores, S. Effect of germinated black bean cotyledons (Phaseolus vulgaris L.) as an extruded flour ingredient on physicochemical characteristics, in vitro digestibility starch, and protein of nixtamalized blue maize cookies. Starch/Staerke 2017, 69, 1-10. [CrossRef]

26. Azarpazhooh, E.; Boye, J.I. Composition of processed dry beans and pulses. In Dry Beans and Pulses Production, Processing and Nutrition; Siddiq, M., Uebersax, M.A., Eds.; Blackwell Publishing Ltd.: Oxford, UK, 2012; ISBN 9780813823874.

27. Singh, Y.; Chandra, S. Evaluation of physical properties of kidney beans (Phaseolus vulgaris). Food Sci. Res. J. 2014, 5, 125-129. [CrossRef]

28. Miano, A.C.; Saldaña, E.; Campestrini, L.H.; Chiorato, A.F.; Augusto, P.E.D. Correlating the properties of different carioca bean cultivars (Phaseolus vulgaris) with their hydration kinetics. Food Res. Int. 2018, 107, 182-194. [CrossRef]

29. Swanson, B.G.; Hughes, J.S.; Rasmussen, H.P. Seed Microstructure: Review of water imbibition in legumes. Food Struct. 1985, 4, 115-124.

30. Miano, A.C.; Augusto, P.E.D. The hydration of grains: a critical review from description of phenomena to process improvements. Compr. Rev. Food Sci. Food Saf. 2018, 17, 352-370. [CrossRef]

31. Meng, G.T.; Ma, C.Y. Thermal properties of Phaseolus angularis (red bean) globulin. Food Chem. 2001, 73, 453-460. [CrossRef]

32. Zhang, Y.H.; Tang, C.H.; Wen, Q.B.; Yang, X.Q.; Li, L.; Deng, W.L. Thermal aggregation and gelation of kidney bean (Phaseolus vulgaris L.) protein isolate at $\mathrm{pH}$ 2.0: Influence of ionic strength. Food Hydrocoll. 2010, 24, 266-274. [CrossRef]

33. Boye, J.; Zare, F.; Pletch, A. Pulse proteins: Processing, characterization, functional properties and applications in food and feed. Food Res. Int. 2010, 43, 414-430. [CrossRef]

34. Schwenke, K.D. Reflections about the functional potential of legume proteins: A review. Nahr.- Food 2001, 45, 377-381. [CrossRef]

35. Yu, S.; Jiang, L.Z.; Kopparapu, N.K. Impact of Soybean 7S Globulin Content on Thermal and Retrogradation Properties of Nonwaxy Corn Starch. J. Food Nutr. Res. 2015, 54, 41-49.

36. Wang, H.; Ratnayake, W.S. Physicochemical and Thermal Properties of Phaseolus vulgaris L. var. Great Northern Bean Starch. J. Food Sci. 2014, 79, C295-C300. [CrossRef]

37. Li, J.Y.; Yeh, A.I. Functions of starch in formation of starch/meat composite during heating. J. Text. Stud. 2002, 33, 341-366. [CrossRef]

38. López-Barón, N.; Gu, Y.; Vasanthan, T.; Hoover, R. Plant proteins mitigate in vitro wheat starch digestibility. Food Hydrocoll. 2017, 69, 19-27. [CrossRef]

39. Joshi, M.; Aldred, P.; Panozzo, J.F.; Kasapis, S.; Adhikari, B. Rheological and microstructural characteristics of lentil starch-lentil protein composite pastes and gels. Food Hydrocoll. 2014, 35, 226-237. [CrossRef]

40. Jyothi, A.N.; Sasikiran, K.; Sajeev, M.S.; Revamma, R.; Moorthy, S.N. Gelatinisation properties of cassava starch in the presence of salts, acids and oxidising agents. Starch/Staerke 2005, 57, 547-555. [CrossRef]

41. Zhou, H.; Wang, J.; Li, J.; Fang, X.; Sun, Y. Pasting properties of Angelica dahurica starches in the presence of $\mathrm{NaCl}, \mathrm{Na}_{2} \mathrm{CO}_{3}, \mathrm{NaOH}$, glucose, fructose and sucrose. Starch/Staerke 2011, 63, 323-332. [CrossRef]

42. Oomah, B.D.; Patras, A.; Rawson, A.; Singh, N.; Compos-Vega, R. Chemistry of Pulses. In Pulse Foods: Processing, Quality and Nutraceutical Applications; Tiwari, B.K., Gowen, A., McKenna, B., Eds.; Academic Press: San Diego, CA, USA, 2011; pp. 9-55, ISBN 9780123820181.

43. Chakraborty, P.; Sosulski, F.; Bose, A. Ultracentrifugation of salt-soluble proteins in ten legume species. J. Sci. Food Agric. 1979, 30, 766-771. [CrossRef]

44. Debet, M.R.; Gidley, M.J. Three classes of starch granule swelling: Influence of surface proteins and lipids. Carbohydr. Polym. 2006, 64, 452-465. [CrossRef]

45. Voragen, A.C.J.; Rolin, C.; Marr, B.U.; Challen, I.; Riad, A.; Lebbar, R.; Knutsen, S.H. Polysaccharides. In Ullmann's Encyclopedia of Industrial Chemistry; Wiley-VCH Verlag GmbH \& Co.: Weinheim, Germany, 2003; Volume 29, pp. 417-473, ISBN 9783527306732.

46. Palabiyik, İ.; Toker, O.S.; Karaman, S.; Yildiz, Ö. A modeling approach in the interpretation of starch pasting properties. J. Cereal Sci. 2017, 74, 272-278. [CrossRef] 
47. Champagne, E.T.; Bett, K.L.; Vinyard, B.T.; McClung, A.M.; Barton, F.E.; Moldenhauer, K.; Linscombe, S.; McKenzie, K. Correlation between cooked rice texture and rapid visco analyser measurements. Cereal Chem. 1999, 76, 764-771. [CrossRef]

48. Wu, G.; Morris, C.F.; Murphy, K.M. Evaluation of texture differences among varieties of cooked Quinoa. J. Food Sci. 2014, 79, S2337-S2345. [CrossRef]

49. Otegbayo, B.; Aina, J.; Asiedu, R.; Bokanga, M. Pasting characteristics of fresh yams (Dioscorea spp.) as indicators of textural quality in a major food product-“pounded yam". Food Chem. 2006, 99, 663-669. [CrossRef]

(C) 2020 by the authors. Licensee MDPI, Basel, Switzerland. This article is an open access article distributed under the terms and conditions of the Creative Commons Attribution (CC BY) license (http://creativecommons.org/licenses/by/4.0/). 